\title{
Banking Capital and Risk-taking Adjustment under Capital Regulation: The Role of Financial Freedom, Concentration and Governance Control
}

\author{
Shu Ling Lin* \\ Vational'Taipei Iniversity of Technology, Thiiwin \\ Dar-Yeh Hwang

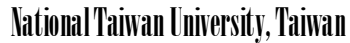 \\ Keh Luh Wang \\ lational Chilio Thung Iniversity, Thiwiwn \\ Zhe Wen Xie \\ Ir'mly Service, Repulblic of (thinit

\begin{abstract}
This study analyzes the relevance of capital adjustment and risk-taking adjustment during the financial tsunami when the banking industry was under capital regulation. Using the panel data of commercial banks in the USA and non-USA from 2003 to 2009, we consider the effects of financial freedom, concentration and governance control simultaneously by threestage least square analysis. The results show that capital and risk adjustment are positively correlated for both USA and nonUSA banking industry, which are consistent after the financial tsunami. This applies to the verification of the capital buffer theory. In addition, for banks with low capital adequacy ratio, capital and risk adjustment are negatively correlated. This applies to the verification of bankruptcy cost avoidance theory and managerial risk aversion theory. Finally, banks with lower capital ratio will be faster in the adjustment of risk-taking as compared with banks with higher capital ratio. This study recommended that supervision should be coupled with governance control to achieve the goal of reducing risk-taking.
\end{abstract} \\ Keywords: Capital regulation, risk-taking, capital buffer \\ theory, concentration, governance control. \\ JEL: G21, G28
}

Overly depending on the deposit insurance has made the depositors ignore the credit risk caused by excessive bank lending. According to the rating agency of S\&P, by March 2008, the major global financial institutions have accumulated asset write-downs worth more than 280 billion USD due to investments in subprime borrowerrelated securities. The series of defaults or bankruptcy events in the financial industry

Manuscript received March 15, 2013; revised May 15, 2013; accepted June 10, 2013.

*Corresponding author Email: shuling@ntut.edu.tw triggered by subprime crisis led to the global financial tsunami.

To protect the interests of the depositors and reduce the risk-taking by the banks, financial authorities have regulated bank's capital adequacy ratio in order to reduce the amount of non-performing loans. Actually, before the financial tsunami, the capital adequacy of many banks has been beyond the Basel minimum capital requirement. However, during the tsunami, top ranking banks and financial institutions showed just the opposite and went 
bankrupt. Therefore, we intend to explore the relevance of capital adjustment and risk adjustment in banking industry under the regulation of minimum capital requirement.

Prior literature suggests that the effect of bank capital regulation on risk-taking is uncertain. Koehn and Santomero (1980) and Kim and Santomero (1988) argued that strengthening capital regulation will encourage the bank to pursue higher risk-taking. However, Furlong and Keeley (1989) pointed out that higher degree of capital regulation will reduce bank' $s$ motivation to increase risky assets. Shrieves and Dahl (1992) suggested that the effect of capital regulation actually conflicts with the expectation of the financial supervisor. This is because the restriction on leverage due to capital regulation will make leverage and risky asset substitute to each other. With 288 banks from 48 countries as samples, Laeven and Levine (2009) applied the $z$-score and stock market variation to measure the relationship between capital regulation and risk-taking. Their empirical results did not find significant negative relevance between capital regulation and risk-taking. In sum, the above studies suggest that the relationship between capital regulation and risk-taking is not consistent.

Behr et al. (2009) further examined the relationship between bank capital regulation and risk-taking, and argued that some other factors that might affect the results were neglected, namely, the bank franchise value and the degree of competition. Demsetz et al. (1996) indicated that the franchise value represents the present value of expected future earnings from the corporations. It reduces the incentive of the bank to take excessive risk. With rising franchise value, the bank tends not to engage in high risk investment which may result in huge losses or even bankruptcy. Behr et al. (2009) used the non-performing loan as the indicator for the risk and measured the correlation between capital regulation and risk-taking. They found that banking industry with lower degree of concentration has lower level of franchise value, and its capital regulation and risk-taking are significantly and negatively correlated. On the contrary, the banking industry of higher concentration has higher level of franchise value, and the relationship between capital regulation and risk-taking is not significant. This means that capital regulation can reduce bank' s risk-taking when the degree of market competition is high.

Even though prior literature has considered the effect of market structure, only current capital regulation has been considered in the analysis of the correlation between capital regulation and risk-taking. Agoraki et al. (2010) found that current regulatory pressure may not be able to produce an immediate effect on the risk-taking of the bank. In particular, when the market structure changes, it will produce a time delay effect. Therefore, Agoraki et al. (2010) used the dynamic and static models, and found that market forces are closely related to lower degree of credit risk and degree of default risk. The capital regulation of the prior period can reduce risk-taking. With rising market forces, this phenomenon will gradually reduce and even produce the opposite results. Therefore, strengthening the market forces of the prior period or enhancing the bank 


\section{Lin et al.}

capital regulation can promote the reduction of credit risk and default risk. Hence, the supervisory role can produce direct impact on the risk-taking of the bank rather than through market forces.

According the definition of Heritage Research $(2013)^{1}$, the financial freedom is a measure of banking efficiency as well as a measure of independence from government control and interference in the financial sector. The freedom categories include rule of law, limited government, regulatory efficiency and open markets. In an ideal banking and financing environment where a minimum level of government interference exists, independent central bank supervision and regulation of financial institutions are limited to enforcing contractual obligations and preventing fraud. There are five areas which are considered to assess an economy' s overall level of financial freedom that ensures easy and effective access to financing opportunities for people and businesses in the economy. The five indexes include as follows: The extent of government regulation of financial services, the degree of state intervention in banks and other financial firms through direct and indirect ownership, the extent of financial and capital market development, government influence on the allocation of credit, and openness to foreign competition.

Based on the above, capital regulation and risk-taking are considerably correlated. In particular, financial freedom, competitiveness and governance control should be considered

1 http://www.heritage.org/index/financial-freedom. simultaneously. In addition, under involuntary capital regulation, the bank may reduce its risktaking; however, when facing risk changes, the bank may carry out capital adjustment proactively. This study differs in the following aspects: Considering the occurrence of the financial tsunami has produced a transformation period for financial freedom, competitiveness and governance control, this study explores the correlation between capital adjustment and risktaking adjustment in the USA and non-USA banking industries under the current and prior period of regulation pressure, and emphasize the effects after the financial tsunami. The objectives of this study are summarized as follows:

1. By considering the financial freedom, competitiveness and governance control, this study explores the correlation between capital adjustment and risk-taking adjustment under capital regulation in the current and prior periods of the USA and non-USA banking industries during 2003-2009.

2. In terms of capital regulation, this study applies the approach considering capital varieation to measure the degree of regulation pressure to test the capital buffer theory, bankruptcy cost avoidance theory, the managerial risk aversion theory and the competition-fragility theory.

3. To test the robustness, this study compares the differences between the full period of 20032009 and after the financial tsunami.

\section{LITERATURE REVIEW}

Since 1980, research on the correlation between capital adjustment and risk adjustment has been 
started. Due to regulation, Buser et al. (1981) argued that leverage of most banks are accrued by slightly exceeding the minimum capital regulatory requirements to balance the external and hidden costs caused by reduced profits of high-leveraged. In such a leveraged operation, financial supervisors will adjust the hidden costs relating to the bank asset risk or capital requirement ratio to guide the banks to adjust to the most appropriate capital adequacy ratio. Therefore, the adjustment of risk and the adjustment of capital adequacy ratio of the bank will be positively correlated. The capital regulation allows the bank to pursue investment of higher risk level when increasing the capital requirement and the higher degree of risk-taking will force the bank under regulation pressure to increase its capital requirement. Therefore, capital regulation will lead to risk-based capital adequacy provision standards. When the bank is facing binding requirements of capital regulation, risk adjustment and capital adjustment are positively correlated.

\section{Effects of capital adjustment on risk-taking adjustment}

Heid et al. (2004) and Jokipii and Milne (2010) argued that the most important contribution of the capital buffer theory is to distinguish the relationship between capital regulation and the allocation of risky assets, capital ratio and risktaking into the long term and short term relationships. In long term, capital ratio and risktaking may be positively or negatively correlated. However, in short term, the correlation between capital ratio and risk-taking is determined by the bank's level of capitalization. For highly capitalized banks, Jokipii and Milne (2010) have expected the capital ratio and risk-taking are positively correlated. On the contrary, the capital ratio and risk-taking are negatively correlated in case of banks failing the minimum capital requirements of the regulatory norms. When the capital regulation norms require more capital requirement, in the short term, it will reduce the level of capital buffer. Therefore, in short term, the capital regulatory norms will encourage the bank to reduce the level of capital buffer. Shrieves and Dahl (1992) and Matejaš ák and Teplý (2007) have argued that according to the bank bankruptcy cost avoidance theory, the cost of bank bankruptcy is the increasing function of its bankruptcy opportunities. Therefore, if the bankruptcy opportunities increase, the bank will tend to increase its capital requirement. In addition, according to the managerial risk aversion theory, managers as the shareholders' agents will have more incentives to reduce the default risk of the bank. Therefore, in the face of rising risk, the managers will increase capital requirement to compensate for the increasing risk. Hence, the capital adjustment and risktaking adjustment are expected to be positively correlated. Heid et al. (2004) have argued that according to the moral hazard theory, in the face of the capital regulation, the bank will be forced to increase its capital requirement, resulting in consequent increase in the allocation of risky assets. Shrieves and Dahl (1992) have argued the effects of capital regulation are in conflict with the expectations of financial supervisors as the restrictions on leveraged operations will make risky assets the substitute of the leverage. Since 


\section{Lin et al.}

the bank experiences involuntary leverage reduction, the capital regulation gives rise to the increase in capital requirement; the bank will increase risky assets to achieve the pursued total risk. Similarly, when the regulation allows the bank to reduce its capital requirement, the bank will reduce its risky assets, indicating that the capital ratio and risk-taking level of the banks close or below the minimum capital requirements are positively correlated.

In addition, from the perspective of governance, Laeven and Levine (2009) argued that investors with minority investment in the bank will tend to favor of making the bank to take more risk as compared with the management or depositors not holding the bank equity. If the financial supervisors can induce the investors to enhance shareholding in the bank, it can reduce the incentives of the investors to pursue risktaking. Laeven and Levine (2009) have found that when the shareholders of the bank have larger cash flow rights, the bank will tend to have higher degree of risk-taking. Therefore, neglecting the ownership structure will result in incomplete or wrong conclusions regarding the impact of capital regulation, deposit insurance, operation activity on the risk-taking of the bank. Kim and Santomero (1994) also agreed to the above reasoning results, confirming capital regulation does not ensure the investors to invest more capital in bank. On the contrary, Koehn and Santomero (1980) and Buser et al. (1981) have argued capital regulation may increase the risk of the bank as the investors will choose investment portfolios of higher risk degree to compensate its utility loss under stricter capital regulation (leverage loss), and thus enhancing the agency problem. Berger (1995), Kisgen (2006) and Peura and Keppo (2006) have expressed that the bank management will emphasize the franchise value, credit rating, default probability if they are risk averse. When the capital regulation requirements enhance its capital adequacy ratio, the bank will take the initiative to enhance the proportion of capital assets.

From the perspective of the bank failure opportunity cost, when the bank failure probability increases, the indirect failure cost will increase. Therefore, proper risk management can reduce its bankruptcy cost. When the bank failure (bankruptcy) cost reduces, its operating cost will reduce accordingly to increase the net cash flow of the bank. In addition, in case of higher franchise value of the bank, the bank will have higher bankruptcy cost, and thus will tend to engage in lower risk of investment decision. On the contrary, in a highly competitive market, the bank' $s$ franchise value will be reduced to result in falling bankruptcy cost accordingly. To enhance the competitive advantage of the bank, the bank will tend to engage in higher risk of investment decision. Demsetz et al. (1996) have argued, the bank can more stably create profits and improve its franchise value when the competitiveness is restricted. If the bank loan quality, Ioan value or efficiency is better, its franchise value will improve. To keep its hard earned franchise value, banks with higher degree of franchise value will operate more robustly. Therefore, banks of higher level of franchise value will tend to have higher capital adequacy ratio then the requirement of the capital regulation to 
avoid exposure to high loan risk, and will have diversified loan portfolio of good quality. Carletti (2008) has also argued that in a lower competitive market, the bank will have higher profitability, capital ratio and franchise value due to large amounts of loan opportunities, which encourage the bank to reduce the incentives to take excessive risk. Therefore, in this case, the bankruptcy probability will be lower. Behr et al. (2009) have proposed that capital regulation should be able to effectively reduce the risktaking of the bank. However, in a highly competitive market, the bank' $s$ franchise value will be lower. To enhance its franchise value, capital regulation will encourage the bank to pursue more risky investment. Boyd et al. (2006) have proposed two models to predict the correlation between bank bankruptcy risk and the competition degree without reaching consistent conclusions.

Bolt and Tieman (2004), in a dynamic framework, have advocated that strict capital regulatory norms will result in the more stringent formulation of the loan decision criteria of the bank. Similarly, Hellmann et al. (2000) have argued that when the bank's franchise value reduces and the degree of competition increases, the bank' $s$ willingness to stringent loans will be lowered. Higher profitability will provide buffer to the impact of the adverse information and result in the increase of the bank' $s$ franchise value, reducing the bank's incentive to pursue excessive risk-taking. Allen and Gale (2000, 2004) have proposed that in terms of the impact of banks' competition on stability, large banks will have better degree of diversification. Hence, the banking system of large banks will be more stable with lower risk degree as compared with the banking system of a small bank. In addition, since large banks are easier to supervise, corporate governance controls will be more efficient in the banking system of large banks and the adverse impact of the risks will be more insignificant. Lindquist (2004) have argued that large banks facing capital regulation will have lower degree of pressure as they are too big to fall. Therefore, large banks are expected to have lower degree of capital requirement. Aggarwal and Jacques (2001) have argued that large banks tend to hold less capital and have more space to increase capital issuing when comparing with other banks in necessity.

Under capital regulation, the empirical studies suggest that the relationship between capital ratio and risk will be determined by whether the required capital ratio of the bank is beyond the minimum capital regulation requirement (Shrieves and Dahl, 1992; Heid et al., 2004; Rous et al., 2010). In other words, in the face of capital regulation, banks of lower capital ratio will increase capital to meet the regulatory requirements and reduce their risk-taking at the same time. On the contrary, banks of higher capital ratio will increase capital requirement to meet the regulatory requirements and increase risk-taking at the same time. Therefore, the empirical results suggest that the capital regulatory requirements can affect the formulation decision-making of the capital ratio by the bank and have an actual supervising effect on the risktaking of the bank (Murinde and Yaseen, 2004; Godlewski, 2004; Matejaš ák and Teplý, 2007). 


\section{Lin et al.}

Delis and Staikouras (2009) have found that capital regulation and supervision transparency are complementary to each other. Using the capital regulatory norms only to manage the risktaking of the bank may not be able to really play the effectiveness of supervision. Angkinand et al. (2010) have pointed out that whether the loose interest rate and credit policies will result in bank crisis is determined by the strength of capital regulation and supervision. Under loose capital regulation and supervision, the probability of bank crisis will increase and vice versa.

In terms of the empirical studies on the correlation between market competition and risk, it is found that when the degree of competition and loan/capital ratio are positively correlated, the degree of competition and risk-taking will be negatively correlated (Boyd et al., 2006; Behr et al., 2009). In case of the increasingly competitive banking industry, Repullo (2002) has considered two regulatory tools of capital requirement and deposit interest ceiling, finding that they have preventive effects on excessive risk-taking in the incompletely competitive deposit market. Barth et al. (2001) and VanHoose (2007) have pointed out that the supervision by using capital regulation only may not necessarily contribute to the safety and robustness of the banking industry, and other tools are needed sometimes. The concurrent use of capital regulation and supervision policy can promote bank performance and stability to encourage the bank to reduce its risk level. On the contrary, when the bank is in a market of low competition level, due to higher level of Ioan value and franchise value, its operation will be safer. Therefore, banks with high level of franchise value will have more capital requirement and have fewer loan portfolios of risky assets. Hence, the credit risk taking is indirectly affected by market forces (Demsetz et al., 1996; Magalhaes et al., 2008; Agoraki et al., 2010; Stephanou, 2010). On the other hand, Magalhaes et al. (2008) have found that when the protective laws and regulations of the state governance controls for shareholders are more imperfect, the impact of bank regulation on the risk will be more important.

In summary, previous empirical studies have not reached consistent conclusions regarding the correlation between capital and risk in case of capital regulation. This study infers, as market competitiveness or financial freedom degree has not been considered concurrently in previous studies, it may result in the different correlations of capital adjustment and risk adjustment in case of capital regulation. Niinimaki (2004) have argued that when considering different market structures, if the banking industry is of a monopolistic or lending market is of perfect competition, the deposit insurance will have no significant impact on the risk-taking of the bank. However, in the face of deposit market competition, the bank will have lower level of franchise value. As a result, its credit risk or default risk will increase, and the deposit insurance may increase the risk-taking of the bank.

Shrieves and Dahl (1992) and Matejaš ák and Teplý (2007) have proposed that according to bank bankruptcy cost avoidance theory, the bankruptcy cost is the increasing function of the bankruptcy opportunity. Therefore, in the face of 
rising bankruptcy risk, the bank will tend to increase its capital ratio. In addition, according to the proposition of managerial risk aversion theory, the management as the agents of the shareholders will have more incentives to reduce the bank default risk as compared with the shareholders as they may suffer personal losses in case of bank default. Hence, in the face of rising risk, the management will increase bank capital to trade off the rising risk. The empirical results of Heid et al. (2004) have found that bank capital and risk-taking are positively correlated. Therefore, this study expects that capital adjustment and risk-taking adjustment are positively correlated.

According to capital buffer theory, Shrieves and Dahl (1992) and Matejaš ák and Teplý (2007) have found that banks of lower capital adequacy ratio will increase its capital and reduce its risk-taking when faced with involuntary regulatory pressure. Heid et al. (2004) have also found that in the face of capital regulation, banks of lower capital adequacy ratio will attempt to increase capital ratio and reduce its risk-taking. On the contrary, banks of relatively higher capital adequacy ratio will increase capital and risktaking concurrently. Moreover, Murinde and Yaseen (2004) have also found that capital regulation can affect the capital decision of the bank significantly. However, the regulatory norm will not encourage the bank to increase its capital ratio but have a positive impact on the risk decision making of the bank.

Behr et al. (2009) have stated that, market structure will affect the impact of capital regulation on the risk-taking of the bank. Agoraki et al. (2010) have believed that strict capital regulation will result in entry barrier to the financial market and restrict competition. As a result, existing banks will accumulate its market forces to have more stringent and lower risk of investment behaviors. Carletti (2008) has argued that due to large amount of loan opportunities, higher profitability, higher capital ratio and higher franchise value, banking systems of smaller competitiveness will have lower possibility of bankruptcy. Hence, it provides banks with motivations to reduce the pursuit of the excess risk-taking. Demsetz et al. (1996) have argued, in case of restricted competitiveness, the bank can create profits more stably to improve the franchise value. To keep such profitability value, the bank prefers to have higher capital ratio than the requirement of the capital regulation. Therefore, according to the proposition of the competition-fragility theory, this study expects that reducing the level of competition will encourage the bank to reduce its risk-taking and enhance its capital ratio adjustment.

According to according to capital buffer theory, bankruptcy cost avoidance theory, managerial risk aversion theory and the competition-fragility theory, this study applies the relationship between capital adjustment and risktaking adjustment as summarized from the empirical results by Shrieves and Dahl (1992), Matejaš ák and Teplý (2007), and the relationship between capital ratio and risk adjustment as advocated by Behr et al. (2009) and Agoraki et al. (2010). On the bases of literature review following hypotheses if proposed: 


\section{Lin et al.}

$\mathrm{H}_{1}$ : Considering the degree of concentration, banks of higher capital adequacy ratio in the face of current capital regulation will enhance its risk-taking adjustment.

$\mathrm{H}_{2}$ : Condisering the degree of concentration, banks of lower capital adequacy ratio in the face of current capital regulation will reduce its risk-taking adjustmen.

\section{Effects of Adjustment Speed}

In addition, Heid et al. (2004) have furthermore proposed on the basis of the capital buffer theory that banks of lower capital buffer will be faster in adjusting capital and risk-taking as compared with banks of higher capital buffer. Coupled with consideration of the degree of concentration, this study proposes the following hypothesis.

$\mathrm{H}_{3}$ : Considering the degree of concentration, banks of lower capital adequacy ratio will be faster in the adjustment of risk-taking as compared with banks of higher capital adequacy ratio.

\section{Effects of time lag}

Moreover, in addition to the possible impact of the current period regulation on risk-taking adjustment, the prior period regulation may also affect the current period risk adjustment. Therefore, the empirical results by Agoraki et al. (2010) regarding the impact of the prior period capital regulation on the current period risktaking, the result showed that the prior period capital regulation and the current period risktaking are significantly negatively correlated. However, when considering the degree of concentration, the effect is unclear. Therefore, this study proposes the following hypothesis.
$\mathrm{H}_{4}$ : Considering the degree of concentration, when the bank of lower capital adequacy ratio is faced with current or prior capital regulation, it will reduce its adjustment of risk-taking.

\section{Interaction effects between regulation and concentration}

Agoraki et al. (2010) have found that new regulation has no immediate impact on the risktaking of the bank, in particular, when the degree of concentration changes. If regulation can affect risk-taking, then the prior period regulation may have impact at the current period when considering the degree of concentration. In addition, on the basis of the competition-fragility theory, Demsetz et al. (1996) and Carletti (2008) have argued that reducing the level of competition can encourage the bank to have higher capital ratio and reduce its bankruptcy opportunities. Coupled with consideration of the degree of concentration and further to verify the competition-fragility theory, to understand the interactive effects of concentration (the level of competition reduction) together with capital regulation, this study proposes the following hypothesis.

$\mathrm{H}_{5}$ : When the concentration increases (reduction in the level of competition), risk-taking adjustment will reduce.

$\mathrm{H}_{6}$ : Considering the degree of concentration, when the bank of lower capital adequacy ratio is faced with current or the prior period regulation, higher level of interaction of the two will result in lower level of risk-taking adjustment.

Considering the financial tsunami, the effects of capital adjustment on risk-taking adjustment: 
Previous literature on the correlation between capital adjustment and risk adjustment rarely takes into consider the impact of the financial events of the market. Therefore, this study will specifically discuss the impact of the financial tsunami on capital adjustment and risk-taking adjustment.

Banking is highly leveraged. When the asset size grows by leverage to cause the too big to fall, the probability of a financial crisis will increase. Moreover, Shrieves and Dahl (1992) have stated that with the subsidy mechanism of deposit insurance, when the bank is faced with rising deposits, it does not need to bear additional default risk premium, which helps enhance marginal profits. However, when marginal benefits increase with rising risky asset, it will increase the leverage of the bank (capital reduction). Therefore, when deposit insurance subsidy mechanism has dominated the investment behavioral of the bank, the capital adjustment and risk adjustment are expected to be negatively correlated, and the bank will tend to reduce its provision for capital adequacy ratio and increase its risk-taking. In view of this, this study further explores whether the correlation between bank capital adjustment and risk-taking adjustment after the financial tsunami is consistent with the expectations of the capital buffer theory, bank bankruptcy cost avoidance theory, and managerial risk aversion theory by proposing the following hypothesis.

$\mathrm{H}_{7}$ : After the occurrance of financial tsunami, risk-taking adjustment will be reduced.

\section{METHODLOGY}

\section{Empirical model}

According to the above hypotheses, this study proposes the empirical model of risk-taking adjustment as follows:

$d R I S K_{i, t}=C_{0}+\beta_{1} S_{L Z E_{i, t}}+\beta_{2}$ LLOSS,$t_{,}+\beta_{3}$ CIR $_{i, t}+\beta_{4} d C A R_{i, t}+\beta_{5} R E G_{, t}+\beta_{6} R E G_{, t-1}-\beta_{7} R I S K_{i, t-1}$ $+\beta_{8}\left(R E G_{, t} \times d C A R_{, t}\right)-\beta_{9}\left(R E G_{, t} \times R I S K_{i, t-1}\right)+\beta_{10}$ GROWTH $+\beta_{11} C O N C E N+\beta_{12}(C O N C E N \times R E G$ )$+\beta_{13}\left(C O N C E N \times R E G_{-1}\right)+\beta_{14} K K Z_{-} C O M P Q+\beta_{15} B F R E E+v_{i, t}$

….....(1)

Where, regulation variable $\left(R E G_{i, t}^{b}\right)$ considers the capital ratio variability as defined below:

$$
\begin{aligned}
& R E G^{b}{ }_{i, t}=1, \text { ifCAR }_{i, t}<8 \%+\sqrt{\operatorname{VAR}\left(C A R_{i, t}\right)} \\
& R E G^{b}{ }_{i, t}=0, \quad \text { otherwise. }
\end{aligned}
$$

When verifying the capital buffer theory, it is expected $\beta_{4}>0$ in this study, namely, risk adjustment and capital adjustment are positively correlated. In case of the bank of lower capital adequacy ratio, the capital and risk adjustment are expected to be negatively correlated. In other words, it is expected $\left(\beta_{4}+\beta_{8}\right)<0$. This applies in the verification of bankruptcy cost avoidance theory and managerial risk aversion theory. On the contrary, when the bank of greater capital buffer is faced with regulatory pressure, the correlation of capital adjustment and risk adjustment is opposite to the expectations of this study, namely, the two are positively correlated $\left(\beta_{4}+\beta_{8}\right)>0$. Shrieves and Dahl (1992), Keohn and Santomero (1980) and Kim and Santomero (1988) have argued that the effects of capital regulation are in conflict with the expectations of the authorities. The reason is that regulation causes restrictions in leverage, making leverage and risky assets are mutually substitutes. 


\section{Lin et al.}

Since the bank has experienced involuntary leverage reduction, that is, regulation has caused capital increase; it will encourage the bank to increase its risky assets to achieve the pursued total risk. Similarly, when the regulatory pressure allows the bank to reduce capital, the bank will reduce risky assets. This implies that in case of banks with capital very close to the minimum capital requirement, the risk and capital are positively correlated. In addition, Kim and Santomero (1994) have stated that regulation does not result in more investment of the bank shareholders.

When verifying the competition-fragility theory, $\beta_{11}<0$ is expected in this study, namely, when the concentration increases (reduction in the level of competition), risk-taking adjustment will reduce. Similarly, $\beta_{12}<0$ is expected in this study, indicating the capital adjustment will increase under the interactive function of concentration and current period regulation while the risk-taking adjustment will reduce. Finally, when verifying whether the regulatory has any delay effect, we expect $\beta_{13}<0$, namely, the interaction of the prior period regulation and concentration (the level of competition) is negatively correlated to risk-taking adjustment.

In addition, the variable of risk-taking adjustment $\left(d R I S K_{i, t}\right)$ is the risk-taking adjustment of $i_{\text {th }}$ bank in period $t$ measured by the non-performing loans ratio $\left(N P L r_{i, t}\right)$, where, $i=1,2,3 \cdots . . \mathrm{N} ; t$ is the study period $(2003 \sim 2009)$; $d C A R_{i, t}$ is the capital adequacy ratio adjustment of $i_{\text {th }}$ bank in period $t ; S I Z E_{i, t}$ is the size of $i_{\text {th }}$ bank in period $t$; $\operatorname{LLOSS}_{i, t}$ is the loan loss ratio of $i_{\text {th }}$ bank in period $t ; C I R_{i, t}$ is the ratio of the non-operating cost against the total income of $i_{\text {th }}$ bank in period t; $R E G_{i, t}^{b}$ is the regulation pressure of $i_{\text {th }}$ bank in period $t ; G R W T H_{t}$ is the economic growth rate in period $t ; C O N C E N_{t}$ is the level of banking industry competition in period $t$; $K K Z_{-} \mathrm{COMPO}_{t}$ reflects the statistical compilation of responses on the quality of governance of the banking industry in period $t$, including six aggregate indicators: Voice and accountability, political stability and absence of violence, government effectiveness, regulatory quality, rule of law, and control of corruption. Finally, $B F R E E_{t}$ is the financial freedom in period t. This indicator has been widely used as a proxy of the degree of openness of the banking industry.

This study furthermore verifies whether there is any significant difference in the impact of capital adjustment on risk adjustment after the financial tsunami. Therefore, in the regression equation (1), $D$ variable is added.

$d R I S K_{, t}=C_{0}+\beta_{1}$ SIZE $_{i, t}+\beta_{2}$ LLOSS $_{, t}+\beta_{3}$ CIR $_{, t}+\beta_{4} d C A R_{, t}+\beta_{5} R E G_{t, t}+\beta_{6} R E G_{t, t-1}-\beta_{7} R I S K_{i, t-1}$ $+\beta_{8}\left(R E G_{i, t} \times d C A R_{t,}\right)-\beta_{9}\left(R E G_{i, t} \times R I S K_{i,-1}\right)+\beta_{10} G R O W T H+\beta_{11} C O N C E N+\beta_{12}(C O N C E N \times R E G$ )$+\beta_{13}\left(C O N C E N \times R E G_{t-1}\right)+\beta_{14} K K Z_{-} C O M P Q+\beta_{15} B F R E E_{-}+\beta_{16} D+v_{i, t}$

............... (2)

Where $D$ represents the dummy variable before and after the financial tsunami, with $D=1$ indicate the time period after the financial tsunami (namely, 2009) and $D=0$ indicate the 
time period before the financial tsunami (namely, 2003-2008).

\section{Definitions of the Variables}

Definitions of the variables used in the empirical model are illustrated as follows.

\section{-Non-performing loans ratio}

Non-performing loans ratio is the ratio of overdue loans divided by total gross loans. When the greater the non-performing loans ratio, the bank's credit risk is higher. Shrieves and Dahl (1992), Behr et al. (2009) and Agoraki et al. (2010) have used the non-performing loans ratio as the proxy variable of risk, and its formula is:

$$
N P L r_{i, t}=\frac{N P L_{i, t}}{T G L_{i, t}}
$$

Where, $N P L_{i, t}$ is non-performing loans of $\dot{i}_{\text {th }}$ bank in period $t, T G L_{i, t}$ is the total gross loans of $i_{\text {th }}$ bank in period $t, i=1,2,3 \cdots . . N, t$ is the study period (2003 2009).

The regression equation (1) and (2) by referring to the $R I S K_{i, t}$ regression equation of Shrieves and Dahl (1992), Matejaš ák and Teplý (2007), Heid et al. (2004), uses $R I S K_{i, t-1}$ to analyze adjustment speed of risk. $\beta_{7}$ value is between 0 and 1 . When $\beta_{7}$ approaches 0 , it means the speed to adjust to the normal average level is very fast. When $\beta_{7}$ is close to 1 , it means the speed to adjust to the normal average level is very slow.

\section{-Adjustemnts of capital ratio and risk-taking}

When verifying the correlation between capital and risk, Shrieves and Dahl (1992), Heid et al.
(2004), Matejaš ák and Teplý (2007) and Jokipii and Milne (2010) have used the adjustments of capital ratio to measure the capital adjustments. Heid et al. (2004) have stated that using capital ratio and the ratio of risk-weighted assets to measure the capital and risk respectively is based on the definition of Basel capital adequacy ratio. To comply with the minimum capital requirement of 8 percent, the bank will adjust the numerator of the Basel capital adequacy ratio (i. e. the total capital) and denominator (i.e. the total riskweighted assets). The capital adjustment is measured by $d C A R_{i, t}$ while the risk adjustment is measured by $d R I S K_{i, t}$.

$$
\begin{gathered}
d C A R_{i, t}=\alpha\left(C A R_{i, t}^{*}-C A R_{i, t-1}\right)+\varepsilon_{i, t} \\
d R I S K_{i, t}=\beta\left(R_{\left.I S K_{i, t}^{*}-R I S K_{i, t-1}\right)+v_{i, t}}\right.
\end{gathered}
$$

Where, $C A R_{i, t}^{*}$ and $R I S K_{i, t}^{*}$ are the optimal capital ratio and risk of $j_{\text {th }}$ bank in period $\mathrm{t}$ respectively. $C A R_{i, t-1}$ and $R I S K_{i, t-1}$ are the actual capital ratio and actual risk of $i_{\text {th }}$ bank in the prior period. $d C A R_{i, t}$ and $d R I S K_{i, t}$ are the capital ratio adjustment and risk adjustment, $\left(C A R_{i, t}^{*}-C A R_{i, t-1}\right)$ and $\left(\operatorname{RISK}_{i, t}^{*}-\right.$ RISK $\left._{i, t-1}\right)$ are the endogenous adjustment of capital ratio and risk, $\varepsilon_{i, t}$ and $v_{i, t}$ are the exogenous factors of capital ratio and risk, $\alpha$ and $\beta$ are the speed to get to the optimal level of capital ratio and risk respectively.

\section{-Regulation pressure $\left({ }^{R E G_{i, t}^{b}}\right)$}

In this study, we use the capital ratio variability to measure regulation ( $R E G_{i, t}^{b}$ ). As the bank 


\section{Lin et al.}

capitalization level will affect the effect of regulation pressure on risk adjustment under capital regulation, Shrieves and Dahl (1992) and Matejaš ák and Teplý (2007) have used the gap magnitude method to measure the capital regulation pressure facing the bank, as illustrated by the following equation.

$$
\begin{aligned}
& R E G^{a}{ }_{i, t}=8 \%-C A R_{i, t}, \text { ifCAR } R_{i, t}<8 \% \\
& R E G^{a}{ }_{i, t}=0, \quad \text { otherwise }
\end{aligned}
$$

However, under the gap magnitude method, banks may have same capital ratio, making it impossible to confirm that they are under different level of regulatory pressure. Therefore, this study considers the capital ratio variability to measure the regulation pressure as defined below.

$$
\begin{aligned}
& R E G^{b}{ }_{i, t}=1, \text { ifCAR } R_{i, t}<8 \%+\sqrt{\operatorname{VAR}\left(C A R_{i, t}\right)} \\
& R E G^{b}{ }_{i, t}=0, \quad \text { otherwise }
\end{aligned}
$$

Where, $C A R_{i, t}$ is the capital ratio of $i_{\text {th }}$ bank in period $t, \sqrt{\operatorname{VAR}\left(C A R_{i, t}\right)}$ is the standard deviation of the capital ratio of $i_{\text {th }}$ bank in period $t$.

Agoraki et al. (2010) have pointed out that new regulatory system will not have immediate effect on the risk-taking behaviors of the bank, especially, when the degree of competition is changing. If regulation can indeed affect the risktaking, the relationship will be delayed by the expected new regulations or new policies to transfer to more healthy banking operation. Therefore, regression equations (1), (2) have considered that the prior period regulation
$\left(R E G_{i, t-1}^{b}\right)$ is expected to affect the bank risktaking of the current period.

\section{Bank characteristics variables}

-Size ( $\left.S I Z E_{i, t}\right)$ : The natural logarithm of the total assets of $i_{\text {th }}$ bank in period $t$.

Shrieves and Dahl (1992), Matejaš ák and Teplý (2007) and Behr et al. (2009) have pointed out that large banks have relatively advantages in diversification, and thus the risk-taking behaviors will be affected. On the other hand, Aggarwal and Jacques (2001) have pointed out that large banks may have less capital and better capability to increase their capital to compare with other banks if necessary. Therefore, this study expects that the size $\left(S I Z E_{i, t}\right)$ and risk-taking are negatively correlated.

$S I Z E_{i, t}=\operatorname{Ln}\left(T A_{i, t}\right)$

Where, $T A_{i, t}$ are the total assets of $i_{\text {th }}$ bank in Period $t$.

-Loan loss reserve ratio $\left(L L O S S_{i, t}\right)$ : The loan loss reserve divided by total loans of $i_{\text {th }}$ bank in period $t$.

Matejaš ák and Teplý (2007), Heid et al. (2004) and Jokipii and Milne (2010) have argued that the higher loan loss reserve ratio in the current period ( $\left.L L O S S_{i, t}\right)$ will reduce the asset recovery in the future, promoting the risk-taking. Therefore, this study expects that the loan loss reserve ratio ( $L L O S S_{i, t}$ ) and risk-taking are positively correlated. 


$$
\operatorname{LLSS}_{i, t}=\frac{\operatorname{Bad~Debts}_{i, t}}{\operatorname{LOAN}_{i, t}}
$$

Where, Bad Debts $_{i, t}$ is the bad loan expenses of $i_{\text {th }}$ bank in Period $t, \mathrm{LOAN}_{i, t}$ is the total loans of $i_{\text {th }}$ bank in Period $t$.

-The ratio of non-operating expenses against the total revenue ( $\left.C I R_{i, t}\right)$ : The non-operating expenses divided by total revenue of $i_{\text {th }}$ bank in Period $t$.

Agoraki et al. (2010) and Behr et al. (2009) have used $C I R_{i, t}$ of the cost-revenue ratio as the control variable. According to bankruptcy cost avoidance theory, managerial risk aversion theory and the findings of Shrieves and Dahl (1992), it is found that risk and capital adjustment are positively correlated. Therefore, $C I R_{i, t}$ and risktaking are positively correlated as expected in this study.

$C I R_{i, t}=\frac{\text { Non }- \text { operating expenses } i, t}{\text { Total revenue } i, t}$

Where, Non - operating expenses $i, t$ is the nonoperating cost of $i_{\text {th }}$ bank in Period $t$, Total revenue $i, t$ is the total revenue of $i_{\text {th }}$ bank in Period $t$.

Macroeconomic variables : The economic growth rate in period $t$.

Agoraki et al. (2010) and Behr et al. (2009) used

$\mathrm{GROWTH}_{t}$ to measure the growth rate of macroeconomic, and found that changes of macroeconomic will affect bank risk-taking. Therefore, this study expects that economic growth rate of ( $\left.G R O W T H_{t}\right)$ and risk-taking are negatively correlated.

$$
G R O W T H_{t}=\frac{G D P_{t}-G D P_{t-1}}{G D P_{t}} \times 100 \%
$$

Where, $G D P_{t}$ is the gross domestic product in period t. Higher GDP means better economic development and higher revenue of the bank with lower bankruptcy risks. Therefore, this study expects that economic growth rate $\left(G R O W T H_{t}\right)$ and risk-taking are negatively correlated.

\section{Market structure variables}

-Concentration ( $C O N C E N_{t}$ ): The ratio of the assets of three largest banks of the banking industry against the total assets of the banking industry.

Previous literature measure the market structure include: HHI (Claessens and Laeven, 2004; Schaeck et al., 2009; Boyd et al., 2006), the ratio of the total assets of three or five largest banks against the assets of the banking industry (Behr et al., 2009; Barth et al., 2008; Beck et al., 2003), and Lerner index (Agoraki et al., 2010). Since the data required for Lerner index are costly and not easy to collect, moreover, this study measures the credit risk, which is the risk caused by bank overdue loans, Lerner index has low relevance with the topic of this study. Moreover, the value of $\mathrm{HHI}$ is too large without definite range. As a result, the value produced by $\mathrm{HHI}$ cannot explicitly express the monopolistic levels of the market share. Comparatively, it is easier to obtain the market share of the banks in terms of total assets, which is also correlated to the credit 


\section{Lin et al.}

risk of this study. Therefore, this study uses the market share of the bank in terms of total assets to measure the market structure and the degree of competition ( CONCENt) of the banking industry. The value is between 0 and 1 .

In addition, Behr et al. (2009), Barth et al. (2008) and Beck et al. (2003), for the verification of the competition-fragility (or the franchise value) theory, used the bank market share of total assets to measure the level of competition. When $C O N C E N_{t}$ value is larger, it means that the concentration is higher and the competition level is lower.

$$
\text { CONCEN }_{t}=\frac{\text { Assets of three largest banks }_{\mathrm{t}}}{\text { Assets of all banks }}
$$

Where, numerator is the assets of three largest banks in the banking industry in Period $t$; denominator is the total assets of the all commercial banks and deposit banks of the banking industry in Period $t$. According to the competition-fragility (the franchise value) theory, this study infers that the bank can obtain stable profits under the lower of competition and the franchise value of the bank will be high. Therefore, its risk-taking will be lower.

-Worldwide Governance Indicators (WGI)
$\left(\mathrm{KKZ}_{-} \mathrm{COMPO}_{t}\right)$ : The worldwide governance indicators (WGI) reflect the compilation of responses on the quality of governance produced by World Bank. The six dimensions of governance include: Voice and accountability, government effectiveness, political stability and absence of violence, regulatory quality, rule of law, and control of corruption. Beck et al. (2003) suggested that when the banking industry's governance controls are good, the bank bankruptcy risk will be reduced. When the average weighted index of the above six dimensions of governance factors is higher, the governance control is better. Therefore, this study expects that quality of governance $\left(\mathrm{KKZ}_{-} \mathrm{COMPO}_{t}\right)$ and risk-taking are negatively correlated as the banking system of more developed governance control can more effectively reduce the risk-taking of the banks.

-Financial freedom ( $\left.B F R E E_{t}\right)$ : Financial freedom is a measure of banking efficiency as well as a measure of independence from government control and interference in the financial sector in period $t$. This indicator has been widely used as a proxy of the degree of openness of the banking industry (DemirgucKunt, Laeven and Levine, 2004).

The Index scores an country financial freedom from the Heritage foundation by looking into the following five broad areas: The extent of government regulation of financial services, the degree of state intervention in banks and other financial firms through direct and indirect ownership, the extent of financial and capital market development, government influence on the allocation of credit, and openness to foreign competition. An overall score on a scale of 0 to 100 is given to a country financial freedom through deductions from the ideal score of 100 . When the value is higher, the financial freedom is higher and the restrictions are fewer. Therefore, 
this study expects that financial freedom

$\left(B F R E E_{t}\right)$ and risk-taking are negatively correlated.

\section{Subject, Period and Data Source}

After removing the data of small banks due to missing value, this study selects the data of 366 commercial banks in the USA and 235 commercial banks in other developed countries and the developing countries during the period from 2003 to 2009. Moreover, this study considers whether hypothese based on the capital buffer theory, bank bankruptcy cost avoidance theory, managerial risk aversion theory are true and whether the relationship between capital and risk adjustment will significantly change after the financial tsunami. The financial variable data of the banking industry are taken from the BankScope database; the $K K Z_{-} C O M P O_{t}$ data come from the World Bank, BFREE data source the Heritage Foundation. Table 1

\begin{tabular}{|c|c|c|}
\hline \multicolumn{3}{|c|}{21 Countries (235) } \\
\hline $\begin{array}{c}\text { Brazil } \\
(10)\end{array}$ & $\begin{array}{l}\text { Canada } \\
\text { (23) }\end{array}$ & $\begin{array}{l}\text { China } \\
\text { (7) }\end{array}$ \\
\hline $\begin{array}{l}\text { Czech } \\
(2)\end{array}$ & $\begin{array}{l}\text { Denmark } \\
(5)\end{array}$ & $\begin{array}{l}\text { Estonia } \\
\text { (2) }\end{array}$ \\
\hline Germany & $\begin{array}{l}\text { Hungary } \\
(2)\end{array}$ & $\begin{array}{c}\text { India } \\
(2)\end{array}$ \\
\hline $\begin{array}{l}\text { Japan } \\
(114)\end{array}$ & $\begin{array}{c}\text { Korea } \\
(8)\end{array}$ & $\begin{array}{c}\text { Malaysia } \\
(11)\end{array}$ \\
\hline $\begin{array}{l}\text { Mexico } \\
\text { (2) }\end{array}$ & $\begin{array}{l}\text { Norway } \\
\text { (10) }\end{array}$ & $\begin{array}{c}\text { Russian } \\
\text { (11) }\end{array}$ \\
\hline $\begin{array}{l}\text { Saudi } \\
\text { Arabia }\end{array}$ & $\begin{array}{l}\text { Slovakia } \\
\text { (1) }\end{array}$ & $\begin{array}{l}\text { Slovenia } \\
\text { (2) }\end{array}$ \\
\hline $\begin{array}{l}\text { Switzerland } \\
\text { (2) }\end{array}$ & $\begin{array}{l}\text { Taiwan } \\
\text { (4) }\end{array}$ & $\begin{array}{c}\text { Thailand } \\
\text { (8) }\end{array}$ \\
\hline
\end{tabular}

Note: The numbers in parentheses indicates the number of banks of the country.

Table 1. The non-USA countries

illustrates the non-USA countries and number of banks in parentheses.

\section{Regression Model}

As OLS will produce the problem of violating consistency and the problem of endogenity as $d R I S K_{i, t}$ is the function of $\varepsilon_{i, t}$ and $d R I S K_{i, t-1}$ is also the function of $\varepsilon_{i, t}$, the covariance of the regression coefficient of $d R I S K_{i, t-1}$ and $\varepsilon_{i, t}$ is not zero. According to the 2SLS (two-stage least square method) and 3SLS (three-stage least square method) proposed by Shrieves and Dahl (1992) and Matejaš ák and Teplý (2007), the covariance of the regression coefficient of $C A R_{i, t-1}$ and $\varepsilon_{i, t}$ can be non-zero. In addition, 3SLS mixes the correlation and asymptotical behavior of cross equation to create a parameter estimation equation more effective than 2SLS. Shim (2010) suggested that 3SLS can consider the endogenous of risk equation and provide consistent estimated parameters. Therefore, 3SLS is used for empirical analysis of this study.

\section{RESULTS}

\section{Statistical Summary and Collinearity Test}

This study conducts 3SLS analysis of the 2,562 data samples of 366 commercial banks in the USA and 1,644 data samples of 235 commercial banks in non-USA countries. When using $\mathrm{REG}^{\mathrm{b}}$ to consider the capital regulation pressure measured by capital variability, due to computation of data, the data samples consist of 2,196 samples of the USA and 1,409 data samples in non-USA countries.

Statistical summary of the USA banking industry as shown in Panel A of Table 2 (See Appendix-I) has suggested that the mean and 


\section{Lin et al.}

standard deviation of capital ratio $\left(C A R_{i, t}\right)$ in the period of 2003 2009 are 10.34 percent and 4.82 percent respectively, the mean and standard deviation of non-performing loan ratio $\left(N P L r_{i, t}\right)$ in the period of 2003 2009 are 1.52 percent and 2.96 percent respectively. In addition, the mean and standard deviation of capital adjustment $\left(d C A R_{i, t}\right)$ in the period of 2003 2009 are 0.03 percent and 2.59 percent respectively, the mean and standard deviation of non-performing loan ratio adjustment $\left(d N P L r_{i, t}\right)$ in the period of 2003 2009 are 0.57 percent and 1.89 percent respectively. It suggests that capital adequacy ratio of the USA banking industry is in accordance with the Basel risk-weighted capital adequacy requirement. During the period of 2003 2009, both capital adjustment $\left(d C A R_{i, t}\right)$ and risk adjustment ( $d R I S K_{i, t}$ ) show an increasing trend.

In non-USA countries, statistical summary of the banking industry as shown in Panel B of Table 2 found that the mean and standard deviation of capital ratio $\left(C A R_{i, t}\right)$ in the period of 2003 2009 are 8.23 percent and 5.71 percent respectively. The mean and standard deviation of nonperforming loan ratio $\left(N P L r_{i, t}\right)$ in the period of 2003 2009 are 4.71 percent and 4.32 percent respectively. In addition, the mean and standard deviation of capital adjustment $\left(d C A R_{i, t}\right)$ in the period of 2003 2009 are -2.79 percent and 106.99 percent respectively. The mean and standard deviation of non-performing loan ratio $\left({ }^{N P L r} r_{i, t}\right)$ in the period of 2003 2009 are -0.51 percent and 2.58 percent respectively. It suggests that capital adequacy ratio of the banking industry of non-USA countries are in accordance with the risk-weighted capital adequacy requirement. In addition, capital adjustment tended to decrease while the non-performing Ioan ratio adjustment tended to decline during the period of 2003 2009.

To further verify whether multiple collinearity problems, this study use VIF (Variance inflation factor) for verification. Panel $A$ and Panel $B$ of Table 2 suggests that VIF values of all the variables relating to the USA and non-USA banking industry are below 10, indicating that there is no multiple collinearity problem.

As shown in Table 2, the USA banking industry' $s$ capital ratio is higher than that of the non-USA banking industries. However, its nonperforming loan ratio is relatively lower. In terms of capital adjustment, the capital adjustment of the USA banking industry tends to increase while the capital adjustment of the non-USA banking industry decreases. In terms of non-performing loan ratio adjustment of the USA banking industry tend to increase. However, in case of the nonUSA banking industry, the adjustment of nonperforming loan ratio tends to decrease. In terms of the variance of capital adjustment and nonperforming Ioan ratio adjustment, the variation of the non-USA banking industry is higher than that of the USA banking industry. Regarding financial freedom, the USA banking industry' $s$ financial freedom is 85.71 , and the financial freedom of 
the non-USA countries is 49.28 , suggesting that the USA banking industry enjoys higher level of financial openness. Moreover, in terms of market structure, the USA banking industry' $s$ concentration is 33.98 percent, while the nonUSA countries is 49.83 percent, indicating that competition level of the USA banking industry is higher.

\section{Results of 3SLS}

\section{-The USA Banking Industry}

The correlation between capital adjustment ( $\left.d C A R_{i, t}\right)$ and risk-taking adjustment $\left(d R I S K_{i, t}\right)$ as shown in Table 3 (See Appendix-II) suggests that when considering the regulation pressure measured by capital variability, the 3SLS regression coefficient of Model 1, Model 2 and Model 3 is $0.0967,0.0945,0.4362$ respectively, having reached the 1 percent significance level. This indicates that $d R I S K_{i, t}$ and $d C A R_{i, t}$ is significantly positively correlated. That is, when the capital adjustment of the USA banking industry increases, the risk-taking adjustment will increase accordingly. It means that in case of banks of higher level of capital buffer in the USA banking industry facing the capital regulation, capital adjustment is positively correlated to the risk-taking adjustment. This empirical result is consistent with the expectations of the capital buffer theory proposed in this study $\left(H_{1}\right)$. However, it does not support the expectations of the competition-fragility theory.

Model 3 of Table 3 indicates that the regression coefficient of the effect of capital adjustment $\left(d C A R_{i, t}\right)$ on risk-taking adjustment ( $d R I S K_{i, t}$ ) is 0.4362 , indicating that the relationship is positively correlated reaching 1 percent significance level. The regression coefficient of the effect of $R E G_{i, t}^{b} \times d C A R_{i, t}$ on risk adjustment ( $\left.d R I S K_{i, t}\right)$ is -0.4432 , indicating that the relationship is negatively correlated reaching 1 percent significance level. The addition of the two is smaller than zero ($0.4432+0.4362=\quad-0.0070), \quad$ namely, $\left(\beta_{4}+\beta_{8}\right)<0$. This suggests that banks of lower level of capital buffer in the USA banking industry facing the current capital regulation pressure will reduce the risk-taking adjustment when the capital adjustment increases. This is consistent with the argument proposed in this study $\left(\mathrm{H}_{2}\right)$ and the expectations of the bankruptcy cost avoidance theory and managerial risk aversion theory.

In terms of risk and capital adjustment speed, the empirical results, as shown in Table 3, the regression coefficient of Model 2 and Model 3 is 0.1226 and 0.1178 respectively, having reached 1 percent significance level. This suggests that $R E G_{i, t}^{b} \times R I S K_{i, t-1}$ and $d R I S K_{i, t}$ is significantly negatively correlated. It also means that banks of lower level of capital buffer in the USA banking industry have faster risk adjustment speed. The results are consistent with the expectations of the capital buffer theory as proposed in this study $\left(\mathrm{H}_{3}\right)$. In addition, as the regression coefficient of 


\section{Lin et al.}

the Model 1 in Table 3 is -1.5358 reaching 10 percent significance level, it means that current regulation pressure $\left(R E G_{i, t}^{b}\right)$ and risk adjustment $\left(d R I S K_{i, t}\right)$ are significantly negatively correlated. Therefore, when the USA banking industry is facing the current capital regulation pressure; the risk-taking pursuit will be reduced as expected by this study $\left(H_{4}\right)$.

As shown in Model 1, Model 2, Model 3 in Table 3, the regression coefficient of the interaction impact between current regulation pressure and concentration ( $\mathrm{CONCEN}_{t} \times R E G_{i, t}^{b}$ ) on risk adjustment is $0.0593,0.0428,0.0533$ respectively, having reached the significance level. However, the interaction impact between the prior period regulation pressure and concentration ( $C O N C E N_{t} \times R E G_{i, t}^{b}$ ) has not reached the significance level. This suggests that the empirical results do not support the expectations of $H_{6}$ proposed in this study. In other words, when facing interaction between current period capital regulation and concentration, banks of lower capital adequacy ratio will have higher level of risk-taking adjustment. This empirical result is not consistent with the competition-stability theory as proposed by Beck et al. (2003) and Boyd and DeNicolo (2005), suggesting that higher level of concentration will result in lower competition and higher probability of crisis.

In terms of the bank characteristic variables, Model 1, Model 2, Model 3 in Table 3 suggest that, the regression coefficient of size $\left(S I Z E_{i, t}\right)$ and risk adjustment correlation is -0.0576, $0.0586,-0.0521$ respectively, having reached the 5 percent significance level. This indicates that large banks of the USA. banking industry may have relatively advantages in diversification and therefore, the level of risk-taking is lower. Moreover, the regression coefficient of the correlation between loan loss reserve ratio $\left(\operatorname{LLOSS}_{i, t}\right)$ and risk-taking adjustment is 0.6278 , $0.6236,0.6009$ respectively, having reached 1 percent significance level. This indicates that the rising loan loss reserve ratio can result in reduced recoverable assets, and thus the USA. banking industry will increase its risk-taking. Finally, the regression coefficient of the non-operating expense rate ( $C I R_{i, t}$ ) and risk adjustment correlation is $0.0033,0.0029,0.0031$ respectively, having reached the 1 percent significance level. This indicates that the risktaking will increase when the non-operating expense rate of the USA. banking industry is higher. As a result, when the bank is facing rising risk, it will increase capital requirement in response. In terms of macroeconomic variables, the empirical results of Model 1, Model 2 and Model 3 in Table 3 suggest that, the correlation between economic growth rate $\left(G R O W T H_{t}\right)$ and risk adjustment( $d R I S K_{i, t}$ ) is significantly negative. The regression coefficient is -0.2585 , $0.2598,-0.2248$ respectively, having reached the 1 percent significance level. This suggests that, when the economic growth rate of the USA banking industry increases, the level of risk- 
taking adjustment will reduce. The above empirical results are in accordance with the expectation of this study. Finally, Model 1 and Model 2 in Table 3 (See Appendix-II) suggest that the correlation between governance indicator $\left(\mathrm{KKZ}_{-} \mathrm{COMPO}_{t}\right.$ ) and risk adjustment ( $d R I S K_{i, t}$ ) is negative, and the regression coefficient is $-1.7224,-1.6215$ respectively, having reached 10 percent significance level. This indicates that, with the better of governance quality of the USA banking industry, the risktaking will decrease as expected in this study.

\section{-The non-USA Banking Industry}

As shown in Panel B in Table 4, when considering the regulation pressure measured by capital variability, the regression coefficient of the correlation between capital adjustment ( $d C A R_{i, t}$ ) and risk adjustment ( $d R I S K_{i, t}$ ) in case of Model 1, Model 2, Model 3 is $0.4153,0.3475,0.6640$ respectively, having reached 1 percent significance level as expected by the argument of this study ( $H_{1}$ ) and the capital buffer theory. This indicates that, under the capital regulation, banks of higher capital buffer in the non-USA banking industry will have positive correlation between capital adjustment and risk-taking adjustment.

As the Model 3 in Table 4 (See Appendix-III) suggests, the regression coefficient of the correlation between capital adjustment ( $d C A R_{i, t}$ ) and risk adjustment ( $\left.d R I S K_{i, t}\right)$ is 0.6640 , indicating a significant positive correlation reaching 1 percent significance level. The regression coefficient of the correlation between $R E G_{i, t}^{b} \times d C A R_{i, t}$ and risk adjustment $\left(d R I S K_{i, t}\right)$ is -0.6363 , being significantly negative and reaching 1 percent significance level. The addition of the two is greater than zero $(-0.6363$ $+0.6640=0.0277)$, namely, $\left(\beta_{4}+\beta_{8}\right)>0$, suggesting that the capital adjustment and risk adjustment correlation is positive when facing regulation pressure in case of the banks of lower capital buffer in the non-USA banking industry.

In terms of capital adjustment and risk adjustment speed, Model 2, Model 3 in Table 4 suggest that the regression coefficient of $R E G_{i, t}^{b} \times R I S K_{i, t-1} \quad$ is $\quad 0.0493, \quad 0.0658$ respectively, having reached significance level. This suggests that, the banks of lower capital buffer in the non-USA banking industry have faster risk adjustment speed than banks of higher level of capital ratio as expected by $\mathrm{H}_{3}$ of this study. Furthermore, Model 1, Model 2, Model 3 in Table 4 suggest that the regression coefficient of $R I S K_{i, t-1}$ is $\quad-0.2900,-0.3094,-0.3087$ respectively, having reached 1 percent significance level. In other words, when the nonperforming loan ratio of the non-USA. banking industry in the prior period increases, the banks will decrease the current period risk-taking.

In terms of the impact of the current period regulation pressure on risk adjustment, Model 1 , Model 2 in Table 4 suggest that, the regression coefficient of the effects of regulation pressure on risk adjustment is $-1.9917,-2.5698$ respectively, having reached a significance level. This means 


\section{Lin et al.}

that, the non-USA banks will reduce risk-taking in the face of the current period capital regulation as expected by $\mathrm{H}_{4}$ of this study. Moreover, Model 1, Model 2 in Table 4 suggest that the regression coefficient of the interaction between the prior period regulation pressure and concentration in case of the non-USA banking industry $\left(\operatorname{CONCEN}_{t} \times R E G_{i, t}^{b}\right)$ is $-0.0417,-0.0404$, having reached 10 percent significance level as expected by ${ }{ }_{6}$ proposed in this study.

In terms of bank characteristics variables, Model 1, Model 2, Model 3 in Table 4 suggest that the regression coefficient of the correlation between loan loss reserve ratio $\left(L L O S S_{i, t}\right)$ and risk adjustment is $0.6982, \quad 0.6912,0.5211$ respectively, having reached 1 percent significance level. This suggests that when the loan loss reserve ratio of the non-USA banking industry is higher, the recoverable assets will be fewer, and thus the bank is encouraged to increase its risk-taking. In addition, the regression coefficient of the correlation between the non-operating expense rate $\left(C I R_{i, t}\right)$ and risk adjustment is $0.0157,0.0152,0.0145$ respectively, having reached 1 percent significance level. This suggests that, when the non-operating expense rate of the bank is higher, the bank will increase its risk-taking as expected in this study. In terms of macroeconomic variables, Model 1, Model 2, Model 3 in Table 4 suggest that the regression coefficient of the correlation between economic growth rate $\left(G R O W T H_{t}\right)$ and risk adjustment ( $\left.d R I S K_{i, t}\right)$ is -
$0.0392,-0.0424,-0.0356$ respectively, having reached a significance level. This suggests that, when the non-USA banking industry' s economic growth rate is higher; the bank will reduce its risktaking as expected in this study. The above empirical findings are consistence with the results of the USA banking industry in Table 3.

In terms of governance indicator, Model 1, Model 2, Model 3 in Table 4 suggest that the regression coefficient of the correlation between governance indicator $\left(K K Z Z_{-} C O M P O_{t}\right)$ and risk adjustment $\left(d R I S K_{i, t}\right)$ is $-0.3276,-0.3666$, 0.3941 respectively, having reached 5 percent significance level. This suggests that, the better of governance quality of the non-USA banking industry will reduce the bank bankruptcy risk to encourage the bank to reduce risk-taking as expected in this study and is consistence with the empirical findings of the USA banking industry in Table 3.

\section{Robustness test}

\section{-Considering the financial tsunami for the USA}

As suggested in Table 5 (See Appendix-IV), when regulation pressure measured by capital variability is considered, the 3SLS empirical results after the financial tsunami are mostly the same with the empirical results without considering the occurrence of financial tsunami in Table 3. As shown in Model 1, Model 2 of Table 5 suggest that the occurrence of financial tsunami $(D)$ and risk adjustment ( $\left.d R I S K_{i, t}\right)$ are significantly positively correlated. The regression coefficient value is 0.0004 , having reached 10 percent 
significance level. This suggests that the financial tsunami has encouraged the USA banking industry to increase risk-taking adjustment; however, the arguments of $H_{7}$ are not supported. In addition, Model 1, Model 2, Model 3 in Table 5 suggest that capital adjustment $\left(d C A R_{i, t}\right)$ and risk adjustment $\left(d R I S K_{i, t}\right)$ are positively significantly correlated, the regression coefficient value is $0.0963,0.0941,0.4369$, respectively, having reached 1 percent significance level. This indicates that, after the financial tsunami with rising risk adjustment, in case of the banks of higher capital buffer level in the USA banking industry, capital adjustment and risk adjustment are positively correlated. Hence, the expectation of the capital buffer theory is supported.

\section{-Considering the financial tsunami for the non- USA countries}

As shown in Table 6 (See Appendix-V), the 3SLS empirical results after the financial tsunami are the same with those of Table 4 without considering the occurrence of financial tsunami. As shown in Model 1, Model 2, Model 3 of Table 6 suggest that the correlation between financial tsunami $\left({ }^{D}\right)$ and risk adjustment $\left(d R I S K_{i, t}\right)$ has not reached the significance level, indicating that the occurrence of the financial tsunami has not resulted in the significant change of the non-USA banking industry in its risk-taking. Moreover, Model 1, Model 2, Model 3 in Table 6 suggest that the correlation between capital adjustment $\left(d C A R_{i, t}\right)$ and risk adjustment $\left(d R I S K_{i, t}\right)$ is significantly positive. The regression coefficient is $0.4034,0.3428,0.6574$ respectively, having reached 1 percent significance level. This suggests that, after the financial tsunami, capital adjustment and risk adjustment correlation of the banks of higher level of capital buffer in the nonUSA banking industry is positive, and thus supporting the expectations of the argument of this study ( $\left.H_{1}\right)$ and the capital buffer theory.

Furthermore, Model 1, Model 2, Model 3 in Table 6 suggest that after the financial tsunami, the correlation between governance indicator $\mathrm{KKZ}_{-} \mathrm{COMPO}_{t}$ ) and risk adjustment $\left(d R I S K_{i, t}\right)$ is significantly negative, the regression coefficient is $-0.4259,-0.4516,-0.4809$ respectively, having reached 1 percent significance level. This suggests that, after the financial tsunami, the better of governance quality of the non-USA banking industry, the risk-taking will be reduced. The above empirical results are in accordance with the expectation of this study and the same with the empirical finding when without considering the occurrence of the financial tsunami in Table 4.

\section{CONCLUSION}

Regarding the USA and non-USA banking industries facing capital regulation, this study explores the correlation between capital adjustment and risk adjustment in the period of 2003 2009 from the perspective of financial freedom, concentration and governance control simultaneously. Particularly, the study explores the effects during the periods of the financial tsunami.

According to the 3SLS empirical results, in case of the USA and non-USA banking industry, 


\section{Lin et al.}

the effects of capital adjustment on risk adjustment is positively correlated. In other words, in the face of capital regulation, banks of higher capital ratio will increase capital requirement to meet the regulatory requirements and increase risk-taking at the same time, this result is consistent with the inferences of the capital buffer theory proposed by Heid et al. (2004) and in accordance with the expectation of this study. On the contrary, banks of lower capital ratio will increase capital to meet the regulatory requirements and reduce their risk-taking at the same time, and thus the bank bankruptcy cost avoidance theory and the managerial risk aversion theory, as well as the findings of Shrieves and Dahl (1992) and Matejaš ák and Teplý (2007) and Agoraki et al. (2010) are supported and confirmed. Hence, it can be concluded that the current period capital regulation affect the bank risk and capital adjustment. Furthermore, under the capital regulation pressure, it is found that banks of lower level of capital buffer have faster speed of risk adjustment.

During the periods of the financial tsunami, the better of governance control of the UAS and non-USA banking industry, the risk-taking pursuit tends to reduce. In particular, after the financial tsunami, when the USA and non-USA banking industry' $s$ market competitiveness is higher and the governance controls are healthier, the risktaking pursuit will be reduced. Finally, the USA banking industry' $s$ market competition is fierce than the non-USA banking industry and the capital regulation effects on the USA banking industry are better, indicating that capital regulation can be more effective in supervision of more competitive markets. The empirical findings are consistent with the conclusions of the study by Behr et al. (2009).

In summary, when taking into account of the concentration, financial freedom and governance control at the same time, the positive correlation of capital adjustment and risk adjustment is of relatively lower degree after the financial tsunami. Hence, it is recommended that the regulation should be coupled with governance control to achieve the goal of reducing risk-taking. Based on the empirical findings of this study, we suggest that under different market competition and governance controls, capital regulation is an effective supervision tool. In particular, after the financial tsunami, regulation can play the role of effective financial supervision. Therefore, banks should recognize the importance of risk management, and implement the credit risk management. The financial supervisory authorities should further enhance the risk awareness to promote comprehensive risk management and prudential financial supervision, and strengthen the supervisory cooperation with competent authorities in other countries.

After the financial tsunami, many banks in the USA accepted the funding from the USA governmental program TARP (Troubled Asset Relief Program), which has a considerable impact on the risk-taking of the banks. Therefore, future studies may focus on banks receiving the funding of TARP to furthermore explore the impact of the TARP funding program on the risk-taking of the banks in the USA.

\section{REFERENCES}




\section{International Journal of Management, Economics and Social Sciences}

Aggarwal, R. \& Jacques, K. (2001). The impact of FDICIA and prompt corrective action on bank. capital and risk. Journal of Banking and Finance, 25, 1139-1160.

Agoraki, M.E. K., Delisb, M. D. \& Pasiourasc, F. (2010). Regulations, competition and bank risk-taking in transition countries. Journal of Financial Stability, 7 (1): 38- 48.

Allen, F. \& Gale, D. (2000). Comparing financial systems. MIT Press, Cambridge, MA.

Allen, F. \& Gale, D. (2004). Competition and financial stability. Journal of Money, Credit, and Banking, 36, 453480.

Angkinand, A., Sawangngoenyuang, W. \& Wihlborg, C. (2010). Financial liberalization and banking crises: A crosscountry analysis. Financial crises and global market integration: part II, 10, 263- 292.

Barth, J. R., Caprio, G. \& Levine, R. (2001). The regulation and supervision of banks around the world: A new database. World Bank Policy Research Working Paper, 2588.

Barth, J. R., Caprio, G. \& Levine, R. (2008) Bank regulations are changing: For better or worse. Comparative Economic Studies, 50, 537- 563.

Beck, T., Demirguc-Kunt, A. \& Levine, R. (2003). Bank concentration and crises. World Bank Policy Research Paper, 3041.

Behr, P., Schmidt, R., H. \& Xie, R. (2009). Market structure, capital regulation and bank risk taking. Journal of Financial Services Research, 37, 131- 158.

Berger, A.N. (1995). The relationship between capital and earnings in banking. Journal of Money, Credit and Banking, 27, 432-456.

Bolt, W. \& Tieman, A.F. (2004). Banking competition, risk and regulation. Scandinavian. Journal of Economics, 106, $783-804$.

Boyd, J. H., Nicolò, G. D. \& Jalal, A. M. (2006). Bank risktaking and competition revisited: New theory and new evidence. IMF Working Paper, 297.

Boyd, J. \& De Nicolo, G. (2005). The Theory of Bank Risk Taking Revisited. Journal of Finance, 60, 1329-1343.

Buser, S.A., Chen, A.H. \& Kane, E.T. (1981). Federal deposit insurance, regulatory policy and optimal bank capital. Journal of Finance, 36 (1): 51- 60.

Carletti, E. (2008). Competition and regulation in banking. In Boot, A. \& Thakor, A. (ed.) Handbook of Corporate
Finance, Financial Intermediation and Banking: 449-482. San Diego: Elsevier.

Claessens, S. \& Laeven, L. (2004). What drives bank competition? Some international evidence. Journal of Money, Credit, and Banking, 36, 563- 583.

Delis, M. D. \& Staikouras, P. (2009). On-site audits, sanctions, and bank risk-taking: An empirical overture towards a novel regulatory and supervisory philosophy. MPRA Paper no. 16836, University Library of Munich, Germany.

Demirguc-Kunt, A., Laeven, L. \& Levine, R. (2004) Regulations, market structure, institutions, and the cost of financial intermediation. Journal of Money, Credit and Banking, 36(3): 593-622.

Demsetz, R.S., Saidenberg, M.R. \& Strahan, P.E. (1996) Banks with Something to Lose: The Disciplinary Role of Franchise Value. FRBNY Economic Policy Review, 2(2): 114.

Furlong, F. T. \& Keeley, M. C. (1989). Capital regulation and bank risk-taking: a note. Journal of Banking \& Finance, 13 , 883- 891

Godlewski, C. J. (2004). Capital regulation and credit risk taking: Empirical evidence from banks in emerging market economies. LaRGE Research Center, University of Strasbourg, France.

Heid, F., Porath, D. \& Stolz S. (2004). Does capital regulation matter for bank behavior? Evidence for German savings banks. Discussion Paper Series 2: Banking and Financial Studies no. 3, Deutsche Bundesbank, Germany.

Hellmann, T.F., Murdock, K.C. \& Stiglitz, J.E. (2000). Liberalization, moral hazard in banking, and prudential regulation: are capital requirements, enough? American Economic Review, 90, 147- 165.

Heritage Research. (2013). 2013 index of economic freedom. http://www. heritage.org/index/financial-freedom

Jokipii, T. \& Milne, A. (2010). Bank capital buffer and risk adjustment decisions. Journal of Financial Stability, 7 (3): $165-178$.

Kim, D. \& Santomero, A. (1994). Risk in banking and capital regulation. Journal of Finance, 43, 1219-1233.

Kim, D. \& Santomero, A. M. (1988). Risk in banking and capital regulation. Journal of Finance, 43(5): 1219-1233.

Kisgen, D. (2006). Credit ratings and capital structure. Journal of Finance, 61, 1035-1072. 


\section{Lin et al.}

Koehn, M. \& Santomero, A. (1980). Regulation of bank capital and portfolio risk. Journal of Finance, 35, 12351244.

Laeven, L., \& Levine, R. (2009). Bank governance, regulation, and risk taking. Journal of Financial Economics, 93, 259275 .

Lindquist, K.G. (2004). Bank' s buffer capital: How important is risk. Journal of International Money and Finance, 23(3), 493 - 513.

Magalhaes, R., Gutiérrez, M. \& Tribó, J. A. (2008). Banks' Ownership structure, risk and performance. Working Paper, Department of Business Administration: Universidad Carlos III de Madrid.

Matejaš ák, M. \& Teplý, P. (2007). Regulation of bank capital and behavior of banks: Assessing the US and the EU-15 region banks in the 2000-2005 periods. IES Working Paper, 23.

Murinde, V. \& Yaseen, H. (2004). The impact of Basle accord regulations on bank capital and risk behaviour: $3 D$ evidence from the Middle East and North Africa (MENA) region. Third International Conference of the Centre for Regulation and Competition, on "Pro-Poor Regulation \& Competition: Issues, Policies and Practices" , CapeTown, South Africa.

Niinimaki, J.P. (2004). The effects of competition on banks' risk-taking. Journal of Economics, 81, 199- 222.
Peura, S. \& Keppo, J. (2006). Optimal bank capital with costly recapitalization. Journal of Business, 79, 2163-2201.

Repullo, R. (2002). Capital requirements, market power, and risk-taking in banking. Journal of Financial Intermediation, $13,156-182$.

Rous, P., Soedarmono, W. \& Tarazi A. (2010). Bank capital requirement, managerial self interest and risk taking: Evidence from Indonesian banks. Faculty of Law and Economic Science, University of Limoges, France.

Schaeck, K., Cihak, M., Wolfe, S. (2009). Are more competitive banking systems more stable? Journal of Money, Credit and Banking, 41(4): 711- 734.

Shim, J. (2010). Capital-based regulation, portfolio risk and capital determination: Empirical evidence from the US property- liability insurers. Journal of Banking \& Finance, 34(10): 2450- 2461.

Shrieves, R. \& Dahl, D. (1992). The relationship between risk and capital in commercial banks. Journal of Banking and Finance, 16, 439- 457.

Stephanou, C. (2010). Rethinking market discipline in banking: lessons from the financial crisis. World Bank Policy Research Working Paper, 5227.

VanHoose, D. (2007). Theories of bank behavior under capital regulation. Journal of Banking \& Finance, 31(12): 36803697. 
Appendix-1

\begin{tabular}{|c|c|c|c|c|c|c|}
\hline \multicolumn{7}{|c|}{ Panel A: The USA } \\
\hline & CAR & dCAR & NPLr & dNPLr & REG & CIR \\
\hline Mean & 10.34 & 0.03 & 1.52 & 0.57 & 0.29 & 64.45 \\
\hline Std. Dev. & 4.82 & 2.59 & 2.96 & 1.89 & 0.45 & 32.18 \\
\hline Median & 9.37 & 0.11 & 0.56 & 0.06 & 0.00 & 61.00 \\
\hline Maximum & 79.82 & 22.27 & 50.50 & 25.55 & 1.00 & 702.54 \\
\hline Minimum & -4.79 & -72.94 & 0.00 & -10.91 & 0.00 & 1.16 \\
\hline Skewness & 6.57 & -12.63 & 6.04 & 4.28 & 0.94 & 8.76 \\
\hline Kurtosis & 69.79 & 332.65 & 62.94 & 35.40 & 1.89 & 142.24 \\
\hline VIF & & 1.22 & & & 1.99 & 1.13 \\
\hline \multicolumn{2}{|c|}{ Observations 2562} & 2562 & 2562 & 2562 & 2562 & 2562 \\
\hline & SIZE & LLOSS & GROWTH & CONCEN & BFREE & KK_COMPO \\
\hline Mean & 14.69 & 0.57 & 1.59 & 33.98 & 85.71 & 1.26 \\
\hline Std. Dev. & 1.72 & 1.17 & 2.02 & 5.15 & 4.95 & 0.06 \\
\hline Median & 14.49 & 0.19 & 2.49 & 34.94 & 90.00 & 1.25 \\
\hline Maximum & 21.28 & 13.31 & 3.57 & 40.33 & 90.00 & 1.34 \\
\hline Minimum & 9.15 & -1.94 & -2.63 & 25.03 & 80.00 & 1.16 \\
\hline Skewness & 0.71 & 4.32 & -1.15 & -0.37 & -0.29 & -0.19 \\
\hline Kurtosis & 3.94 & 29.04 & 2.97 & 1.93 & 1.08 & 2.09 \\
\hline VIF & 1.06 & 1.54 & 6.07 & 8.05 & 4.38 & 1.98 \\
\hline Observations & 2562 & 2562 & 2562 & 2562 & 2562 & 2562 \\
\hline \multicolumn{7}{|c|}{ Panel B: The non-USA countries (21 developed and developing countries) } \\
\hline & CAR & dCAR & NPLr & dNPLr & REG & $\mathrm{CIR}$ \\
\hline Mean & 8.23 & -2.79 & 4.71 & -0.51 & 0.72 & 60.41 \\
\hline Std. Dev. & 5.71 & 106.99 & 4.32 & 2.58 & 0.45 & 18.47 \\
\hline Median & 6.31 & 0.05 & 3.80 & -0.31 & 1.00 & 60.35 \\
\hline Maximum & 70.06 & 59.14 & 41.30 & 21.90 & 1.00 & 271.66 \\
\hline Minimum & -17.57 & -4332.98 & 0.00 & -45.50 & 0.00 & 13.53 \\
\hline Skewness & 3.18 & -40.37 & 2.44 & -3.81 & -0.99 & 2.27 \\
\hline Kurtosis & 24.49 & 1634.34 & 14.06 & 73.86 & 1.98 & 22.32 \\
\hline VIF & & 1.30 & & & 3.67 & 1.43 \\
\hline \multicolumn{2}{|c|}{ Observations 1644} & 1644 & 1644 & 1644 & 1644 & 1644 \\
\hline & SIZE & LLOSS & GROWTH & CONCEN & BFREE & KK_COMPO \\
\hline Mean & 16.43 & 0.01 & 2.12 & 49.83 & 49.28 & 0.89 \\
\hline Std. Dev. & 1.86 & 0.01 & 3.61 & 10.47 & 15.36 & 0.67 \\
\hline Median & 16.66 & 0.00 & 2.20 & 47.18 & 50.00 & 1.16 \\
\hline Maximum & 21.43 & 0.16 & 14.19 & 100.00 & 90.00 & 1.85 \\
\hline Minimum & 10.79 & -0.05 & -13.90 & 30.00 & 30.00 & -0.72 \\
\hline Skewness & -0.31 & 6.41 & -0.19 & 2.23 & 0.75 & -1.05 \\
\hline Kurtosis & 3.18 & 69.33 & 4.30 & 9.37 & 3.39 & 2.98 \\
\hline VIF & 1.45 & 1.23 & 1.43 & 1.83 & 2.11 & 2.15 \\
\hline Observations & 1644 & 1644 & 1644 & 1644 & 1644 & 1644 \\
\hline
\end{tabular}


Appendix-II

$d R I S K_{i, t}=C_{0}+\beta_{1} \operatorname{SIZE}_{i, t}+\beta_{2}$ LLOSS $_{i, t}+\beta_{3}$ CIR $_{i, t}+\beta_{4} d C A R_{i, t}+\beta_{5} R E G_{i, t}+\beta_{6} R E G_{i, t-1}-\beta_{7} R_{2} I S K_{i, t-1}$

$+\beta_{8}\left(R E G_{i, t} \times d C A R_{i, t}\right)-\beta_{9}\left(R E G_{i, t} \times R_{I S K_{i, t-1}}\right)+\beta_{10}$ GROWTH $_{t}+\beta_{11}$ CONCEN $_{t}+\beta_{12}\left(\operatorname{CONCEN}_{t} \times R E G_{t}\right.$

)$+\beta_{13}\left(\mathrm{CONCEN}_{t} \times R E G_{t-1}\right)+\beta_{14} K K Z_{-} \mathrm{COMPO}_{t}+\beta_{15} \mathrm{BFREE}_{t}+v_{i, t}$

\begin{tabular}{|c|c|c|c|c|c|c|}
\hline Variables & Model 1 & $p$-value & Model 2 & 2 & $\begin{array}{r}\text { Model } \\
\text { Coefficien }\end{array}$ & $\begin{array}{l}3 \\
t p \text {-value }\end{array}$ \\
\hline Constant & 3.7584 & 0.1079 & 3.7177 & 0.1106 & 3.1962 & 0.2062 \\
\hline$S I Z E_{i . t}$ & -0.0576 & $0.0041^{* \star *}$ & -0.0586 & $0.0034^{* * *}$ & -0.0521 & $0.0158^{\star \star}$ \\
\hline $\operatorname{LLOSS}_{i t}$ & 0.6278 & $0.0000^{* * *}$ & 0.6236 & $0.0000^{* * *}$ & 0.6009 & $0.0000^{* * *}$ \\
\hline$C I R_{i . t}$ & 0.0033 & $0.0019^{\star \star \star}$ & 0.0029 & $0.0065^{\star \star \star}$ & 0.0031 & $0.0064^{\star \star \star}$ \\
\hline$d C A R_{i . t}$ & 0.0967 & $0.0015^{\star * \star}$ & 0.0945 & $0.0018^{* * *}$ & 0.4362 & $0.0008^{* * *}$ \\
\hline$R E G b_{i . t}$ & -1.5358 & $0.0748^{*}$ & -1.0845 & 0.2135 & -1.3771 & 0.1411 \\
\hline$R E G b_{i . t-1}$ & 0.1110 & 0.8953 & -0.0517 & 0.9511 & 0.3971 & 0.6618 \\
\hline$R I S K_{i+1}$ & 0.0705 & $0.0003^{* * *}$ & 0.0211 & 0.3888 & 0.0188 & 0.4767 \\
\hline$R E G_{i . t} \times d C A R_{i . t}$ & & & & & -0.4432 & $0.0006^{\star \star \star}$ \\
\hline$R E G_{i+} \times R I S K_{i+-1}$ & & & 0.1226 & $0.0011^{* * *}$ & 0.1178 & $0.0034^{\star \star \star}$ \\
\hline $\mathrm{GROWTH}_{t}$ & -0.2585 & $0.0000^{* * *}$ & -0.2598 & $0.0000^{* * *}$ & -0.2248 & $0.0000^{\star \star \star}$ \\
\hline CONCEN $_{t}$ & -0.0184 & 0.4678 & -0.0160 & 0.5256 & -0.0017 & 0.9501 \\
\hline$C O N C E N_{t} \times R E G b_{i . t}$ & 0.0593 & $0.0134^{\star \star}$ & 0.0428 & $0.0794^{*}$ & 0.0533 & $0.0432^{\star \star}$ \\
\hline $\operatorname{CONCEN}_{t} \times R E G b_{i . t-1}$ & -0.0084 & 0.7217 & -0.0033 & 0.8880 & -0.0185 & 0.4694 \\
\hline$K K Z \quad C O M P O_{t}$ & -1.7224 & $0.0646^{*}$ & -1.6215 & $0.0813^{*}$ & -1.3815 & 0.1723 \\
\hline BFREE $_{t}$ & 0.0020 & 0.8844 & 0.0011 & 0.9372 & -0.0049 & 0.7475 \\
\hline $\mathrm{R}$-squared & 0.38 & 842 & 0.38 & 882 & 0.2 & 893 \\
\hline Adj. R-square & 0.38 & 806 & 0.38 & 842 & 0.2 & 844 \\
\hline Durbin-Watson & 1.49 & 947 & 1.51 & 186 & 1.6 & 533 \\
\hline$F$-statistic & 117.0 & 0265 & 109.6 & 6465 & 102. & 8060 \\
\hline $\operatorname{Prob}(F-$ statistic $)$ & 0.000 & $00^{* * *}$ & 0.000 & $00^{* * *}$ & 0.00 & $00^{* * *}$ \\
\hline Obs & 2,1 & & 2,1 & & 2,1 & 196 \\
\hline
\end{tabular}

Relationship between capital and risk-taking adjustment of the USA banking industry during the period of 2003-2009 (3SLS): Without considering financial tsunami

Note: ${ }^{R I S K} i, t=$ non-performing loans ratio $\left({ }^{N P L r i, t}\right), \quad R E G^{b}{ }_{i, t}$ is the capital regulation measure by using $R E G^{b}{ }_{i, t}=1, i f C A R_{i, t} \prec 8 \%+\sqrt{\operatorname{VAR}\left(C A R_{i, t}\right)}$

capital variability, that is $R E G_{i, t}^{b}=0, \quad$ otherwise

${ }^{* \star \star}$ Significant at $1 \%,{ }^{* \star}$ Significant at $5 \%,{ }^{*}$ Significant at $10 \%$.

Table 3. Statistics description and collinearity test 


$$
\begin{aligned}
& d R I S K_{i, t}=C_{0}+\beta_{1} S_{Z Z E_{i, t}}+\beta_{2} L_{L O S S}{ }_{i, t}+\beta_{3} C_{2} R_{i, t}+\beta_{4} d C A R_{i, t}+\beta_{5} R E G_{i, t}+\beta_{6} R E G_{i, t-1}-\beta_{7} R_{I S K} K_{i, t-1} \\
& +\beta_{8}\left(R E G_{i, t} \times d C A R_{i, t}\right)-\beta_{9}\left(R E G_{i, t} \times \text { RISK }_{i, t-1}\right)+\beta_{10} \text { GROWTH }_{t}+\beta_{11} \text { CONCEN }_{t}+\beta_{12}\left(\text { CONCEN }_{t} \times \text { REG }_{t}\right. \\
& )+\beta_{13}\left(C O N C E N_{t} \times R E G_{t-1}\right)+\beta_{14} K K Z Z_{-} C O M P O_{t}+\beta_{15} \text { BFREE }_{t}+v_{i, t}
\end{aligned}
$$

\begin{tabular}{|c|c|c|c|c|c|c|}
\hline \multirow{2}{*}{ Variables } & \multicolumn{2}{|c|}{ Model 1} & \multicolumn{2}{|c|}{ Model 2} & \multicolumn{2}{|c|}{ Model 3} \\
\hline & Coefficient & $p$-value & Coefficient & $p$-value & Coefficient & $p$-value \\
\hline Constant & 1.5260 & $0.0844^{*}$ & 1.6434 & $0.0507^{*}$ & 1.1878 & 0.2217 \\
\hline$S I Z E_{i, t}$ & -0.0615 & 0.1193 & -0.0589 & 0.1168 & -0.0213 & 0.6464 \\
\hline $\operatorname{LLOSS}_{i, t}$ & 0.6982 & $0.0000^{* * *}$ & 0.6912 & $0.0000^{* * *}$ & 0.5211 & $0.0000^{* * *}$ \\
\hline$C I R_{i, t}$ & 0.0157 & $0.0001^{\star \star \star}$ & 0.0152 & $0.0000^{* * *}$ & 0.0145 & $0.0003^{\star \star \star}$ \\
\hline$d C A R_{i, t}$ & 0.4153 & $0.0095^{* * *}$ & 0.3475 & $0.0211^{* *}$ & 0.6640 & $0.0053^{* * *}$ \\
\hline$R E G b_{i, t}$ & -1.9917 & $0.0787^{*}$ & -2.5698 & $0.0217^{\star \star}$ & -1.0897 & 0.4358 \\
\hline$R E G b_{i, t-1}$ & 0.7579 & 0.5212 & 0.9551 & 0.3948 & -0.5564 & 0.7023 \\
\hline$R I S K_{i t-1}$ & -0.2900 & $0.0000^{* * *}$ & -0.3094 & $0.0000^{* \star *}$ & -0.3087 & $0.0000^{* * *}$ \\
\hline$R E G_{i, t} \times d C A R_{i, t}$ & & & & & -0.6363 & $0.0067^{* * *}$ \\
\hline$R E G_{i t} \times R I S K_{i t-1}$ & & & 0.0493 & $0.0706^{*}$ & 0.0658 & $0.0332^{* *}$ \\
\hline GROWTH & -0.0392 & $0.0503^{*}$ & -0.0424 & $0.0256^{\star *}$ & -0.0356 & $0.0976^{*}$ \\
\hline$C O N C E N_{t}$ & -0.0085 & 0.4036 & -0.0116 & 0.2367 & -0.0164 & 0.1486 \\
\hline$C O N C E N_{t} \times R E G b_{i, t}$ & 0.0694 & $0.0026^{* \star *}$ & 0.0714 & $0.0012^{* \star \star}$ & 0.0397 & $0.0899^{*}$ \\
\hline$C O N C E N_{t} \times R E G b_{i, t-1}$ & -0.0417 & $0.0577^{*}$ & -0.0404 & $0.0522^{*}$ & -0.0080 & 0.7395 \\
\hline$K K Z_{-} \mathrm{COMPO}_{t}$ & -0.3276 & $0.0102^{\star *}$ & -0.3666 & $0.0027^{\star \star \star}$ & -0.3941 & $0.0034^{* * *}$ \\
\hline$B F R E E_{t}$ & -0.0044 & 0.4273 & -0.0013 & 0.8174 & 0.0003 & 0.9602 \\
\hline R-squared & 0.1 & 174 & 0.20 & 047 & -0.0 & 083 \\
\hline Adj. R-square & 0.1 & 092 & 0.19 & 967 & -0.0 & 192 \\
\hline Durbin-Watson & 1.7 & 520 & 1.69 & 997 & 1.75 & 529 \\
\hline$F$-statistic & 64.8 & 108 & 60.4 & 168 & 56.9 & 976 \\
\hline $\operatorname{Prob}(F-$ statistic $)$ & 0.00 & $00^{* \star *}$ & 0.000 & $00^{\star \star \star}$ & 0.000 & $00^{* \star *}$ \\
\hline Obs & 1,4 & & 1,4 & & & \\
\hline
\end{tabular}

Note: ${ }^{R I S K} i, t=$ non-performing loans ratio $\left({ }^{N P L r i, t}\right), \quad R E G_{i, t}^{b}$ is the capital regulation measure by using

$$
R E G_{i, t}{ }_{i, i f C A R_{i, t}} \prec 8 \%+\sqrt{\operatorname{VAR}\left(C A R_{i, t}\right)}
$$

capital variability, that is $R E G{ }^{b} i, t=0, \quad$ otherwise

${ }^{* * *}$ Significant at $1 \%,{ }^{* *}$ Significant at 5\%, ${ }^{*}$ Significant at $10 \%$.

Table 4. Relationship between capital and risk-taking adjustment of the non-USA banking industry during the period of 2003-2009 (3SLS): Without considering financial tsunami 


\section{Lin et al.}

Appendix-IV

$$
\begin{aligned}
& d R I S K_{i, t}=C_{0}+\beta_{1} \operatorname{SIZE}_{i, t}+\beta_{2} \text { LLOSS }_{i, t}+\beta_{3} \text { CIR }_{i, t}+\beta_{4} d C A R_{i, t}+\beta_{5} R E G_{i, t}+\beta_{6} R E G_{i, t-1}-\beta_{7} R_{S I S K} K_{i, t-1} \\
& +\beta_{8}\left(R E G_{i, t} \times d C A R_{i, t}\right)-\beta_{9}\left(R E G_{i, t} \times \text { RISK }_{i, t-1}\right)+\beta_{10} \text { GROWTH }_{t}+\beta_{11} \text { CONCEN }_{t}+\beta_{12}\left(\text { CONCEN }_{t} \times R^{2} E G_{t}\right.
\end{aligned}
$$

\begin{tabular}{|c|c|c|c|c|c|c|}
\hline \multirow{2}{*}{ Variables } & \multicolumn{2}{|c|}{ Model 1} & \multicolumn{2}{|c|}{ Model 2} & \multicolumn{2}{|c|}{ Model 3} \\
\hline & Coefficient & $p$-value & Coefficient & $p$-value & Coefficient & $p$-value \\
\hline Constant & -0.9054 & 0.7868 & -0.8937 & 0.7889 & -1.0064 & 0.7799 \\
\hline$S I Z E_{i, t}$ & -0.0574 & $0.0042^{\star \star \star}$ & -0.0584 & $0.0035^{\star \star \star}$ & -0.0519 & $0.0161^{\star \star}$ \\
\hline $\operatorname{LLOSS}_{i, t}$ & 0.6276 & $0.0000^{* * *}$ & 0.6234 & $0.0000^{* * *}$ & 0.6008 & $0.0000^{\star * *}$ \\
\hline$C I R_{i, t}$ & 0.0033 & $0.0017^{* \star *}$ & 0.0029 & $0.0059^{* \star *}$ & 0.0031 & $0.0059^{\star \star \star}$ \\
\hline$d C A R_{i, t}$ & 0.0963 & $0.0015^{\text {***}}$ & 0.0941 & $0.0019^{\star \star \star}$ & 0.4369 & $0.0008^{* * *}$ \\
\hline$R E G_{b_{i, t}}$ & -1.5900 & $0.0650^{*}$ & -1.1400 & 0.1908 & -1.4258 & 0.1276 \\
\hline$R E G b_{i, t-1}$ & 0.1433 & 0.8649 & -0.0189 & 0.9821 & 0.4257 & 0.6390 \\
\hline$R I S K_{i t-1}$ & 0.0690 & $0.0004^{* * *}$ & 0.0198 & 0.4183 & 0.0176 & 0.5052 \\
\hline$R E G_{i, t} \times d C A R_{i, t}$ & & & & & -0.4437 & $0.0005^{\star * *}$ \\
\hline$R E G_{i t} \times R I S K_{i t-1}$ & & & 0.1221 & $0.0011^{\star \star \star}$ & 0.1175 & $0.0035^{\star \star \star}$ \\
\hline$G R O W T H_{t}$ & -0.0470 & 0.6838 & -0.0507 & 0.6597 & -0.0343 & 0.7826 \\
\hline$C O N C E N_{t}$ & 0.0466 & 0.2660 & 0.0482 & 0.2484 & 0.0568 & 0.2093 \\
\hline$C O N C E N_{t} \times R E G_{b_{i, t}}$ & 0.0607 & $0.0112^{\star \star}$ & 0.0443 & $0.0692^{*}$ & 0.0547 & $0.0381^{\star \star}$ \\
\hline$C O N C E N_{t} \times R E G b_{i, t-1}$ & -0.0092 & 0.6957 & -0.0041 & 0.8601 & -0.0193 & 0.4512 \\
\hline$K K Z{ }_{-} \mathrm{COMPO}_{t}$ & 0.3913 & 0.7846 & 0.4681 & 0.7430 & 0.5232 & 0.7343 \\
\hline$B F R E E_{t}$ & -0.0065 & 0.6562 & -0.0074 & 0.6146 & -0.0126 & 0.4268 \\
\hline$D_{j}$ & 0.0004 & $0.0519^{*}$ & 0.0004 & $0.0538^{*}$ & 0.0004 & 0.1038 \\
\hline R-squared & 0.3 & 855 & 0.38 & 893 & 0.28 & 898 \\
\hline Adj. R-square & 0.3 & 815 & 0.38 & 851 & 0.28 & 345 \\
\hline Durbin-Watson & 1.4 & 901 & 1.51 & 140 & 1.65 & 505 \\
\hline$F$-statistic & 109. & 0742 & 102.7 & 7108 & 96.7 & 435 \\
\hline $\operatorname{Prob}(F-$ statistic $)$ & 0.00 & $00^{* * *}$ & 0.000 & $00^{* * *}$ & 0.000 & $00^{* * *}$ \\
\hline Obs & 2,1 & 96 & 2,1 & & $2,1 \mathrm{~s}$ & \\
\hline
\end{tabular}

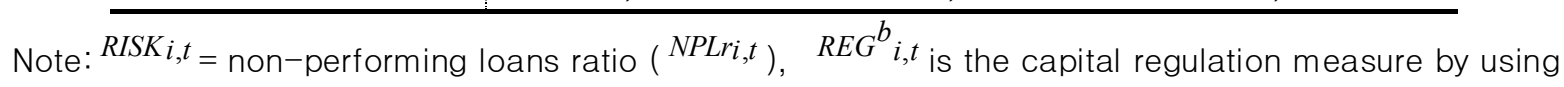

$$
R E G^{b}{ }_{i, t}=1, i f C A R_{i, t} \prec 8 \%+\sqrt{\operatorname{VAR}\left(C A R_{i, t}\right)}
$$

capital variability, that is $R E G^{b}{ }_{i, t}=0, \quad$ otherwise

${ }^{* * *}$ Significant at 1\%, ${ }^{\star *}$ Significant at 5\%, ${ }^{*}$ Significant at $10 \%$.

Table 5. Relationship between capital and risk-taking adjustment of the USA banking industry during the period of 2003-2009 (3SLS): Considering financial tsunami 


\section{Appendix-V}

$d R I S K_{i, t}=C_{0}+\beta_{1} \operatorname{SIZE}_{i, t}+\beta_{2} \operatorname{LLOSS}_{i, t}+\beta_{3} \operatorname{CIR}_{i, t}+\beta_{4} d \operatorname{CAR}_{i, t}+\beta_{5} R_{E G_{i, t}}+\beta_{6} \operatorname{REG}_{i, t-1}-\beta_{7} \operatorname{RISK}_{i, t-1}$ $+\beta_{8}\left(R E G_{i, t} \times d C A R_{i, t}\right)-\beta_{9}\left(R E G_{i, t} \times R_{I S K_{i, t-1}}\right)+\beta_{10}$ GROWTH $_{t}+\beta_{11}$ CONCEN $_{t}+\beta_{12}\left(\right.$ CONCEN $_{t} \times R E G_{t}$

)$+\beta_{13}\left(\operatorname{CONCEN}_{t} \times R E G_{t-1}\right)+\beta_{14} K K Z_{-} C_{C O M P O}+\beta_{15}$ BFREE $_{t}+\beta_{16} D+v_{i, t}$

\begin{tabular}{|c|c|c|c|c|c|c|}
\hline \multirow{2}{*}{ Variables } & \multicolumn{2}{|c|}{ Model 1} & \multicolumn{2}{|c|}{ Model 2} & \multicolumn{2}{|c|}{ Model 3} \\
\hline & Coefficien & t $p$-value & Coefficient & $p$-value & Coefficient & $p$-value \\
\hline Constant & 1.6586 & $0.0592^{*}$ & 1.7522 & $0.0371^{\star \star}$ & 1.3031 & 0.1794 \\
\hline$S I Z E_{i, t}$ & -0.0619 & 0.1130 & -0.0596 & 0.1114 & -0.0222 & 0.6304 \\
\hline $\operatorname{LLOSS}_{i, t}$ & 0.6972 & $0.0000^{\star * \star}$ & 0.6910 & $0.0000^{* * *}$ & 0.5226 & $0.0000^{* * *}$ \\
\hline$C I R_{i, t}$ & 0.0156 & $0.0001^{\star \star \star}$ & 0.0152 & $0.0000^{* * *}$ & 0.0145 & $0.0003^{* * *}$ \\
\hline$d C A R_{i, t}$ & 0.4034 & $0.0109^{* *}$ & 0.3428 & $0.0224^{* *}$ & 0.6574 & $0.0056^{\star * \star}$ \\
\hline$R E G b_{i, t}$ & -1.9823 & $0.0771^{*}$ & -2.5079 & $0.0246^{\star \star}$ & -1.0398 & 0.4552 \\
\hline$R E G b_{i, t-1}$ & 0.6913 & 0.5547 & 0.8772 & 0.4331 & -0.6244 & 0.6667 \\
\hline$R I S K_{i, t-1}$ & -0.2912 & $0.0000^{* * *}$ & -0.3087 & $0.0000^{* * *}$ & -0.3080 & $0.0000^{* * *}$ \\
\hline$R E G_{i, t} \times d C A R_{i, t}$ & & & & & -0.6301 & $0.0070^{\star \star \star}$ \\
\hline$R E G_{i, t} \times R I S K_{i, t-1}$ & & & 0.0448 & 0.1015 & 0.0609 & $0.0489^{\star \star}$ \\
\hline GROWTH $_{t}$ & -0.0726 & $0.0106^{\star *}$ & -0.0722 & $0.0078^{\star \star \star}$ & -0.0662 & $0.0298^{\star \star}$ \\
\hline CONCEN $_{t}$ & -0.0070 & 0.4843 & -0.0101 & 0.3071 & -0.0147 & 0.1942 \\
\hline $\operatorname{CONCEN}_{t} \times R E G_{b_{i, t}}$ & 0.0683 & $0.0028^{\star \star \star}$ & 0.0702 & $0.0013^{\star \star \star}$ & 0.0388 & $0.0957^{*}$ \\
\hline$C O N C E N_{t} \times R E G_{b_{i, t}-1}$ & -0.0391 & $0.0726^{*}$ & -0.0382 & $0.0660^{*}$ & -0.0061 & 0.7994 \\
\hline$K K Z Z_{-} \mathrm{COMPO}_{t}$ & -0.4259 & $0.0023^{\star \star \star}$ & -0.4516 & $0.0007^{\star \star \star}$ & -0.4809 & $0.0011^{\star \star \star}$ \\
\hline BFREE $_{t}$ & -0.0040 & 0.4753 & -0.0011 & 0.8371 & 0.0004 & 0.9442 \\
\hline$D_{j}$ & -0.0002 & 0.1018 & -0.0002 & 0.1248 & -0.0002 & 0.1608 \\
\hline $\mathrm{R}$-squared & 0.13 & 353 & 0.21 & 112 & 0.0 & 015 \\
\hline Adj. R-square & 0.12 & 266 & 0.20 & 027 & -0 & 100 \\
\hline Durbin-Watson & 1.7 & 366 & $1.6 \mathrm{~s}$ & & 1.7 & 473 \\
\hline$F$-statistic & 60.5 & 5464 & 56.6 & 707 & 53.6 & 946 \\
\hline $\operatorname{Prob}(F-$ statistic $)$ & 0.00 & $00^{* * *}$ & 0.000 & $00^{\star \star \star}$ & 0.0 & $00^{* * *}$ \\
\hline Obs & 1,4 & & 1,4 & & 1,2 & 09 \\
\hline
\end{tabular}

Note: ${ }^{R I S K} i, t=$ non-performing loans ratio $\left({ }^{N P L r i, t}\right), \quad R E G^{b}{ }_{i, t}$ is the capital regulation measure by using $R E G^{b}{ }_{i, t}=1, i f C A R_{i, t} \prec 8 \%+\sqrt{\operatorname{VAR}\left(C A R_{i, t}\right)}$ capital variability, that is $R E G^{b}{ }_{i, t}=0, \quad$ otherwise . ${ }^{\star * *}$ Significant at $1 \%,{ }^{* *}$ Significant at $5 \%,{ }^{*}$ Significant at $10 \%$.

Table 6. Relationship between capital and risk-taking adjustment of the non-USA banking industry during the period of 2003-2009 (3SLS): Considering financial tsunami 